\title{
THE EFFECT OF BLADE CURVATURE ANGLE OF SAVONIUS WIND TURBINE L-TYPE ON THE PERFORMANCE
}

\author{
BARLIN $^{1 *}$, CHANDRA OKTAVIAN PRATAMA ${ }^{1}$, \\ KRERRKIAT SASIWIMONRIT ${ }^{2}$ \\ ${ }^{1}$ Department of Mechanical Engineering, Faculty of Engineering, Universitas Sriwijaya, Palembang \\ - 30128, South Sumatera, Indonesia \\ ${ }^{2}$ Department of Mechatronics Engineering, College of Integrated Science and Technology, 98 Moo 8, \\ T. Patpong, Doi Saket District, Chiangmai Province 50220, Thailand \\ *Corresponding author: barlin@ft.unsri.ac.id
}

(Received: 12 January 2021; Accepted: 21 February 2021; Published on-line: 01 March 2021)

\begin{abstract}
The wind is a renewable energy source (alternative energy) as a substitute for the dwindling fossil fuel. L-type Savonius wind turbine is a technology that is widely used to convert wind energy into mechanical because its construction is simple and cheap. The disadvantage of this turbine is having a lower efficiency than other types of wind turbines. Modification of the curvature of the L-type Savonius wind turbine blade is assumed can improve its performance because it affects the direction and magnitude of wind and wheel velocity, consequence impact to power. Thus, the blade angle is interesting to review. There are three angles of blade studied: $30^{\circ}, 45^{\circ}$, and $60^{\circ}$. Based on results, the blade angle influences the performance of the L-type Savonius wind turbine, where the $45^{\circ}$ blade angle produced better performance than $30^{\circ}$ and $60^{\circ}$.
\end{abstract}

KEYWORDS: Wind turbine, L-type Savonius turbine, Blade, Renewable energy

\section{INTRODUCTION}

The wind is a renewable source that can be used as a substitute for fossil fuels [1]. Wind turbines are a technology used to convert wind energy into mechanical energy [2][3]. The wind turbine that is widely used is the L-type Savonius turbine because it has good self-starting capabilities and can operating at low wind speed $(<3 \mathrm{~m} / \mathrm{s})$. The operating conditions of the Ltype Savonius turbine match the characteristics of wind energy in Indonesia, which is an average of $5 \mathrm{~m} / \mathrm{s}$ [4]. Furthermore, The Savonius wind turbine has a simple shape so the investment costs are cheap, easy to manufacture, and do not depend on the wind direction $[5][6][7][8]$.

Due to the abundant potential of wind energy in Indonesia, the downstream wind turbine as an independent power plant continues to be studied. Soelaiman, et.al. (2006) [9] concluded that the L-type blade of the Savonius wind turbine has a better performance than the U-type blade. Mahendra, et.al. (2012) [10] concluded that the performance of the 3 blades type-L Savonius turbine produced higher performance than 2 blades. Ully, et.al. (2017) [11] studied the effect of guide vane on the performance of L-type Savonius turbines and concluded that the guide vane has a positive effect on its performance. This is alleged because the wind velocity vector directed to the blade is converted maximally [11]. 
The disadvantage of the L-type Savonius wind turbine is its performance lower than other types (Darrius, propeller, multiblade, etc.) because of the low torque and rotation generated [7]. This stimulated Bachtiar (2019) [7] to conducted the configuration of the L-type Savonius turbine overlap size. He allegedly the wind that hit the inactive blade through the overlap significantly improved his performance [7], which is believed to be an optimum size for overlap. Feasibility of aluminum as a blade material carried out by Wijiyanti and Saparin (2019) [12]. They studied the effect of using aluminum on the tip speed ratio and concluded that the aluminum runner produced an average TSR of 2 [12], where this value is higher than the graphical dependency TSR with a power coefficient (CP) of 1.5. To increase the torque, the blade angle is a possible alternative. Since the blade configuration affects the direction of the runner velocity so that it affects the torque, the consequence is to power. Thus, the blade angle of the L-type Savonius wind turbine is proposed to be studied.

\section{METHOD}

\subsection{Performance Analysis}

Wind energy potential is a function of the density $(\rho)$, areas (A), and wind speed (V), represented in Eq. 1:

$$
\mathrm{P}_{\mathrm{W}}=\frac{1}{2} \cdot \rho \cdot \mathrm{A} \cdot \mathrm{V}^{3}
$$

The measured power is mechanical power $\left(\mathrm{P}_{\mathrm{T}}\right)$, where its function of torque $(\tau)$ and angular velocity $(\omega)$, represented in Eq. 2:

$$
\mathrm{P}_{\mathrm{T}}=\tau \cdot \omega
$$

The torque is measured using a Prony-brake system (see Fig. 1).

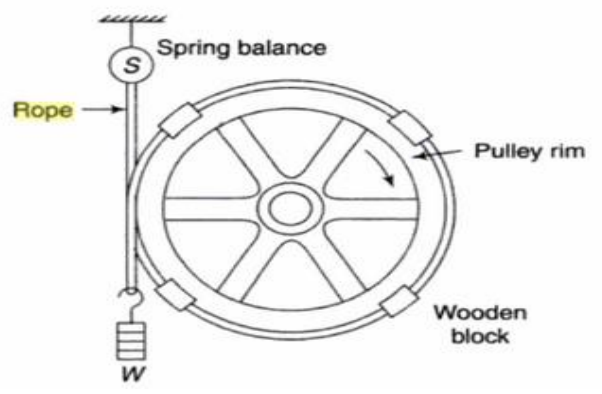

Fig. 1. Schematic of Prony-brake system [13][14]

The principle of the Prony-brake is loading $\left(\mathrm{F}_{1}\right)$, the $\mathrm{F}_{1}$ from 10 gr to 80 gr. Furthermore, friction from the belt with the pulley and $\left(\mathrm{F}_{1}\right.$ is accumulated in the spring balance $\left(\mathrm{F}_{2}\right)$. From Fig. 2, analysis for torque becomes:

$$
\tau=\left(F_{2}-F_{1}\right) \cdot r_{\text {pulley }}
$$

where $r_{\text {pulley }}$ is pulley radius. Whereas, the $\omega$ is measured using a tachometer. The tachometer is measured wheel rotation ( $\mathrm{n})$. The $\mathrm{n}$ converts to the $\omega$ using Eq. 4:

$$
\omega=\frac{2 \cdot \pi \cdot n}{60}
$$

Turbine performance or power coefficient $\left(\mathrm{C}_{\mathrm{P}}\right)$ is a function of $\mathrm{P}_{\mathrm{T}}$ and $\mathrm{P}_{\mathrm{W}}$ :

$$
\mathrm{C}_{\mathrm{p}}=\frac{\mathrm{P}_{\mathrm{T}}}{\mathrm{P}_{\mathrm{W}}} \cdot 100 \%
$$

TSR is the ratio between the runner velocity $(\mathrm{U})$ with V, represented in Eq. 6: 


$$
\operatorname{TSR}=\frac{\mathrm{U}}{\mathrm{V}}
$$

\subsection{L-type Savonius Wind Turbine Configuration}

The L-type Savonius rotor wind turbine (Fig. 1) is a development of the rotor model were it dominantly. absorbs the drag force from the wind [15].

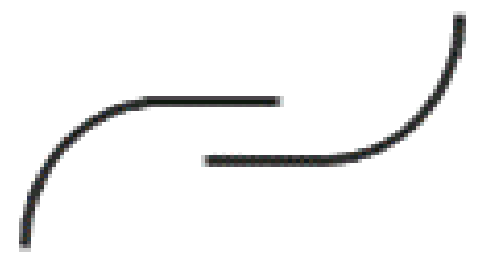

Fig. 2. Schematic of L-type Savonius wind turbine blade

The L-type Savonius turbine model tested has a height of $0.3 \mathrm{~m}$, a width of $0.4 \mathrm{~m}$, blade number is three, runner material is aluminum, and blade angle variation: $30^{\circ}, 45^{\circ}$, and $60^{\circ}$.

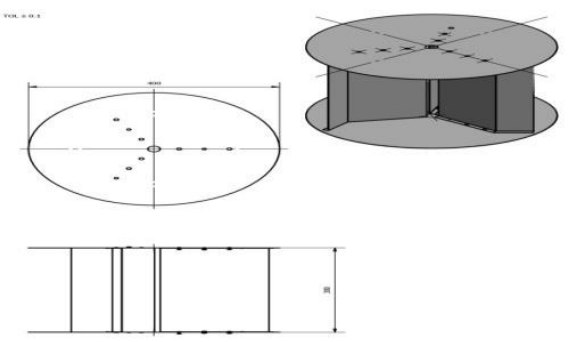

Fig. 3. Dimensions of the L-type Savonius Wind Turbine

\section{RESULTS AND DISCUSSION}

Tables 1,2, and 3 are the results of the runner tests with blade angles of 30, 45, and 60 , respectively. From Tables 1, 2, and 3, the Savonius-L wind turbine that produces the most torque is a curvature angle of $45^{\circ}$. Each loading until the turbine stops, the torque produced by the $45^{\circ}$ Savonius-L wind turbine is the highest compared to $30^{\circ}$ and $60^{\circ}$. The Savonius-L $45^{\circ}$ wind turbine produces the highest power of $0.295 \mathrm{~W}$ (3.27 \% $\eta$ ), while the Savonius-L $30^{\circ}$ produces a power of $0.270 \mathrm{~W}(3.02 \% \mathrm{\eta})$ and the Savonius-L $60^{\circ}$ is $0.260 \mathrm{~W}(2.87 \% \mathrm{\eta})$.

Tabel 1 . The test results of $30^{\circ}$ blade angle

\begin{tabular}{cccccccc}
\hline $\begin{array}{c}\mathbf{n} \\
(\mathbf{r p m})\end{array}$ & $\begin{array}{c}\boldsymbol{\omega} \\
(\mathbf{r a d} / \mathbf{s})\end{array}$ & $\begin{array}{c}\mathbf{F}_{\mathbf{1}} \\
(\mathbf{N})\end{array}$ & $\begin{array}{c}\mathbf{F}_{\mathbf{2}} \\
(\mathbf{N})\end{array}$ & $\begin{array}{c}\Delta \mathbf{F} \\
(\mathbf{N})\end{array}$ & $\begin{array}{c}\boldsymbol{\tau} \\
(\mathbf{N} \cdot \mathbf{m})\end{array}$ & $\begin{array}{c}\mathbf{P}_{\mathbf{T}} \\
(\mathbf{W})\end{array}$ & $\begin{array}{c}\mathbf{C}_{\mathbf{P}} \\
(\boldsymbol{\%})\end{array}$ \\
\hline 112 & 11.72 & 0 & 0 & 0 & 0 & 0 & 0 \\
75 & 7.85 & 0.098 & 1.079 & 0.981 & 0.0343 & 0.270 & 2.99 \\
63 & 6.59 & 0.196 & 1.373 & 1.177 & 0.0412 & 0.272 & 3.019 \\
50 & 5.23 & 0.294 & 1.570 & 1.275 & 0.0446 & 0.234 & 2.595 \\
46 & 4.81 & 0.392 & 1.766 & 1.373 & 0.0481 & 0.231 & 2.572 \\
32 & 3.35 & 0.491 & 1.913 & 1.422 & 0.0498 & 0.167 & 1.853 \\
26.9 & 2.82 & 0.589 & 2.085 & 1.496 & 0.0524 & 0.147 & 1.638 \\
13 & 1.36 & 0.687 & 2.183 & 1.496 & 0.0524 & 0.071 & 0.792 \\
0 & 0.00 & 0.736 & 2.354 & 1.619 & 0.0567 & 0 & 0 \\
\hline
\end{tabular}


Tabel 2. The test results of $45^{\circ}$ blade angle

\begin{tabular}{cccccccc}
\hline $\begin{array}{c}\mathbf{n} \\
(\mathbf{r p m})\end{array}$ & $\begin{array}{c}\boldsymbol{\omega} \\
(\mathbf{r a d} / \mathbf{s})\end{array}$ & $\begin{array}{c}\mathbf{F}_{\mathbf{1}} \\
(\mathbf{N})\end{array}$ & $\begin{array}{c}\mathbf{F}_{\mathbf{2}} \\
(\mathbf{N})\end{array}$ & $\begin{array}{c}\Delta \mathbf{F} \\
(\mathbf{N})\end{array}$ & $\begin{array}{c}\boldsymbol{\tau} \\
(\mathbf{N} \cdot \mathbf{m})\end{array}$ & $\begin{array}{c}\mathbf{P}_{\mathbf{T}} \\
(\mathbf{W})\end{array}$ & $\begin{array}{c}\mathbf{C}_{\mathbf{P}} \\
(\%)\end{array}$ \\
\hline 130 & 13.607 & 0 & 0 & 0 & 0 & 0 & 0 \\
82 & 8.583 & 0.098 & 1.079 & 0.981 & 0.034 & 0.295 & 3.274 \\
63 & 6.594 & 0.196 & 1.472 & 1.275 & 0.045 & 0.294 & 3.270 \\
49 & 5.129 & 0.294 & 1.888 & 1.594 & 0.056 & 0.286 & 3.179 \\
41 & 4.291 & 0.392 & 2.036 & 1.643 & 0.058 & 0.247 & 2.742 \\
27 & 2.826 & 0.491 & 2.183 & 1.692 & 0.059 & 0.167 & 1.860 \\
23 & 2.407 & 0.589 & 2.256 & 1.668 & 0.058 & 0.141 & 1.561 \\
16 & 1.675 & 0.687 & 2.354 & 1.668 & 0.058 & 0.098 & 1.086 \\
0 & 0.000 & 0.785 & 2.403 & 1.619 & 0.057 & 0 & 0 \\
\hline
\end{tabular}

Tabel 3. The test results of $60^{\circ}$ blade angle

\begin{tabular}{cccccccc}
\hline $\begin{array}{c}\mathbf{n} \\
(\mathbf{r p m})\end{array}$ & $\begin{array}{c}\boldsymbol{\omega} \\
(\mathbf{r a d} / \mathbf{s})\end{array}$ & $\begin{array}{c}\mathbf{F}_{\mathbf{1}} \\
(\mathbf{N})\end{array}$ & $\begin{array}{c}\mathbf{F}_{\mathbf{2}} \\
(\mathbf{N})\end{array}$ & $\begin{array}{c}\Delta \mathbf{F} \\
(\mathbf{N})\end{array}$ & $\begin{array}{c}\boldsymbol{\tau} \\
(\mathbf{N} \cdot \mathbf{m})\end{array}$ & $\begin{array}{c}\mathbf{P}_{\mathbf{T}} \\
(\mathbf{W})\end{array}$ & $\begin{array}{c}\mathbf{C}_{\mathbf{P}} \\
(\%)\end{array}$ \\
\hline 101 & 10.571 & 0 & 0 & 0 & 0 & 0 & 0 \\
58 & 6.071 & 0.098 & 1.128 & 1.030 & 0.036 & 0.219 & 2.432 \\
49 & 5.129 & 0.196 & 1.643 & 1.447 & 0.051 & 0.260 & 2.886 \\
41 & 4.291 & 0.294 & 1.717 & 1.422 & 0.050 & 0.214 & 2.374 \\
29 & 3.035 & 0.392 & 1.766 & 1.373 & 0.048 & 0.146 & 1.621 \\
29 & 3.035 & 0.441 & 1.790 & 1.349 & 0.047 & 0.143 & 1.592 \\
21 & 2.198 & 0.491 & 1.815 & 1.324 & 0.046 & 0.102 & 1.132 \\
15 & 1.570 & 0.540 & 1.839 & 1.300 & 0.045 & 0.071 & 0.794 \\
0 & 0.000 & 0.589 & 1.937 & 1.349 & 0.047 & 0 & 0 \\
\hline
\end{tabular}

The curvature angle causes the blade length to be different so that the performance is different. The difference in blade length affects the blade profile (areas), consequence, runner rotation is different. In the Savonius-L turbine $45^{\circ}$, the area that receives wind and holds the wind is not too wide or too small so that the wind flow is more optimal on the turbine blades. Whereas on a curvature angle of $30^{\circ}$, the blade profile that is perpendicular becomes a barrier when it is against the direction of the wind flow (increased drag). For a curvature angle of 60 ${ }^{\circ}$, the large blade curvature causes the wind flow to be obstructed (a drag) thereby reducing the rotation speed of the runner.

\section{CONCLUSION}

Based on the results, the curvature angle $45^{\circ}$ is the right recommendation for the Savonius$\mathrm{L}$ wind turbine where it produces higher turbine power than the curvature angle of $30^{\circ}$ and $60^{\circ}$, namely $0.295 \mathrm{~W}(3.27 \% \mathrm{\eta})$ with a torque of $0.059 \mathrm{Nm}$, and $\omega$ of $8.58 \mathrm{rad} / \mathrm{s}$. 
https://doi.org/10.51630/ijes.v2i1.13

\section{ACKNOWLEDGEMENT}

Thanks to Universitas Sriwijaya for facilities this research.

\section{REFERENCES}

[1] J. Sargolzaei and A. Kianifar, "Modeling and simulation of wind turbine Savonius rotors using artificial neural networks for estimation of the power ratio and torque," Simulation Modelling Practice and Theory, vol. 17, no. 7, pp. 1290-1298, 2009.

[2] J. A. Butbul, "The impact of inertia forces on a morphing wind turbine blade in a vertical axis configuration: A wind tunnel test (Order No. 1561514).," 2014.

[3] T. Klemm, M. Gabi, J.-N. Heraud, T. Klemm, M. Gabi, and J. N. Heraud, “Application of a Cross Flow Fan as Wind Turbine," 2007.

[4] Suharyati, S. H. Pambudi, J. L. Wibowo, and N. I. Pratiwi, "Outlook Energi Indonesia (OEI) 2019," Jakarta, 2019.

[5] J. V. Akwa, H. A. Vielmo, and A. P. Petry, "A review on the performance of Savonius wind turbines," Renewable and sustainable energy reviews, vol. 16, no. 5, pp. 30543064, 2012.

[6] E. Antar and M. Elkhoury, "Casing optimization of a Savonius wind turbine," Energy Reports, vol. 6, pp. 184-189, 2020.

[7] I. K. Bachtiar, "The Effect of Blade Overlap on The Performance of Savonius Wind Turbine," in 2019 IEEE Conference on Energy Conversion (CENCON), 2019, pp. 236239.

[8] C. R. Patel, V. K. Patel, S. V Prabhu, and T. I. Eldho, "Investigation of overlap ratio for Savonius type vertical axis hydro turbine," International Journal of Soft Computing and Engineering, vol. 3, no. 2, pp. 379-383, 2013.

[9] F. Soelaiman, N. P. Tandian, and N. Rosidin, "Perancangan, Pembuatan dan Pengujian Prototipe SKEA Menggunakan Rotor Savonius dan Windside untuk Penerangan Jalan Tol,” Bandung ITB, 2006.

[10] B. Mahendra, R. Soenoko, and D. Sutikno, "Pengaruh Jumlah Sudu Terhadap Unjuk Kerja Turbin Angin Savonius Type L," Jurusan Teknik Mesin Fakultas Teknik, Universitas Brawijaya: Malang, 2013.

[11] D. N. Ully, B. Wuwur, and P. Ginting, "PENGARUH PEMASANGAN SUDU PENGARAH DAN VARIASI JUMLAH SUDU ROTOR TERHADAP PERFORMANCE TURBIN ANGIN SAVONIUS TIPE L," JURNAL FLYWHEEL, vol. 8, no. 1, pp. 25-35, 2017.

[12] E. S. Wijianti and Saparin, "The effect of blade type variations on savonius wind turbine performance," in IOP Conference Series: Earth and Environmental Science, 2019, vol. 353, no. 1, p. 12015.

[13] Budiarso, Helmizar, Warjito, A. Nuramal, W. Ramadhanu, and D. Adanta, "Performance of breastshot waterwheel in run of river conditions," in AIP Conference Proceedings, 2020, vol. 2227, no. 1, p. 20014.

[14] D. P. Sari, Helmizar, I. Syofii, Darlius, and D. Adanta, "The Effect of the Ratio of Wheel Tangential Velocity and Upstream Water Velocity on the Performance of Undershot Waterwheels," Journal of Advanced Research in Fluid Mechanics and Thermal Sciences, 
vol. 65, no. 2, pp. 170-177, 2020.

[15] K. Sahim, D. Santoso, and R. Sipahutar, "Performance of combined water turbine Darrieus-Savonius with two stage Savonius buckets and single deflector," International Journal of Renewable Energy Research (IJRER), vol. 5, no. 1, pp. 217-221, 2015. 